\title{
Life Cycle Assessment to Study the Carbon Footprint of System Components for Colorado Blue Spruce Field Production and Use
}

\author{
Dewayne L. Ingram ${ }^{1}$ \\ Department of Horticulture, University of Kentucky, N-318 Ag Science North, Lexington, KY 40546- \\ 0091
}

\begin{abstract}
AdDitional INDEX words. global warming potential, system analysis, landscape plants, trees, environmental impact, greenhouse gas emissions, Picea pungens

ABstract. The contributions of interrelated production system components of a field-grown, 2-m-tall, 5-cm-caliper Picea pungens (colorado blue spruce) in the upper midwestern (liner) and lower midwestern (finished tree) regions of the United States to its carbon footprint were analyzed using life cycle assessment protocols. The seed-to-landscape carbon footprint was $13.558 \mathrm{~kg}$ carbon dioxide equivalent $\left(\mathrm{CO}_{2} \mathrm{e}\right)$, including sequestration of $9.14 \mathrm{~kg} \mathrm{CO}_{2} \mathrm{e}$ during production. The global warming potential (GWP) from equipment use was the dominant contributor to the carbon footprint of production. Seventy-six percent of the GWP investments during field production occurred at harvest. Querying the model, among other things, revealed that adding one year to the field production phase would add less than $3 \%$ to the seed-to-landscape GWP of the product. The weighted positive impact of carbon (C) sequestration during a 50-year life was $593 \mathrm{~kg} \mathrm{CO}_{2} \mathrm{e}$. After its useful life, takedown and disposal would result in emissions of $148 \mathrm{~kg} \mathrm{CO}_{2} \mathrm{e}$, resulting in a net positive, life cycle impact on atmospheric $\mathrm{CO}_{2}$ of $\approx 431 \mathrm{~kg} \mathrm{CO}_{2} \mathrm{e}$.
\end{abstract}

The nursery industry is often referred to as part of the green industry. However, research to understand how system components of the production and use of landscape plants contribute to environmental impacts such as global warming potential is lacking and will determine the relative sustainability of nursery crop production (Marble et al., 2011; Prior et al., 2011). Therefore, system-level research is needed to provide reliable, reproducible information for scientists, the industry, and the general public.

Greenhouse gases (GHGs), primarily $\mathrm{CO}_{2}, \mathrm{~N}_{2} \mathrm{O}$, and $\mathrm{CH}_{4}$, are increasing in the atmosphere and human activity is contributing to that, primarily through the use of fossil fuels [BSI British Standards, 2011; International Panel on Climate Change (IPCC), 2007]. The GWP of those gases in a standard 100-year assessment period are expressed in relation to the GWP of $\mathrm{CO}_{2}$, which is set as 1 . Although present in the atmosphere at much smaller concentrations, the GWPs of $\mathrm{N}_{2} \mathrm{O}$ and $\mathrm{CH}_{4}$ are 298 and 23, respectively (BSI British Standards, 2011). The production, distribution, and use of products and services result in emission of GHG and thus a carbon footprint, expressed as the GWP of that product or service in kilograms $\mathrm{CO}_{2}$ equivalent.

Life cycle assessment (LCA) is a tool used to quantify the environmental impact of products or services. LCA is a systematic process accounting for environmental impacts of interrelated input components and processes of a product or practice during its complete life cycle, cradle to grave (Baumann and Tillman, 2004). LCA usually includes information on the three primary life phases of a product or service: production phase, use phase, and post-life phase. However, boundaries for a LCA may be referred to as cradle to grave or even cradle to gate, but defining what is the cradle and what is the grave or gate of a product or practice is an important issue. Cradle to grave refers to the

Received for publication 23 Oct. 2012. Accepted for publication 21 Nov. 2012 ${ }^{1}$ Corresponding author. E-mail: dingram@uky.edu. impacts of a product during manufacturing, transport, and use but ends with the impact of that product at the end of its useful life through recycling or disposal. Most published LCAs have focused on carbon footprint, but the tool can be used to assess other environmental impacts such as water footprint, toxicity potential, acidification potential, and resource depletion. International standards govern LCA protocols [BSI British Standards, 2011; International Organization for Standardization (ISO), 2006].

LCA has been used to study agriculture and biofuel production systems and their individual components (Debolt et al., 2009; Hayashi et al., 2006; Liebig et al., 2008; Nemecek et al., 2005, 2006; Williams et al., 2006). Nitrogen fertilizers have been identified as an important component of GHG emissions in agriculture as well as stimulating yield increases (Brentrup and Palliere, 2008; Hillier et al., 2009). Plastic greenhouse covers and containers represented a significant portion of the carbon footprint for floral crops in European LCA studies (Russo et al., 2008; Russo and Mugnozza, 2005; Russo and Zeller, 2008). LCA studies in Europe with forest tree seedling production have shown greenhouse heating and seedling transportation (Aldentun, 2002) and production and disposal of plastics (Cambria and Pierangeli, 2011) to be major GHG emission sources in those systems.

The cutting-to-landscape carbon footprint of a 5-cm-caliper, field-grown, spade-dug Acer rubrum (red maple) was calculated to be $8.2 \mathrm{~kg} \mathrm{CO}_{2} \mathrm{e}$ (Ingram, 2012). Unlike most products, plants take $\mathrm{CO}_{2}$ from the atmosphere and sequester $\mathrm{C}$ to varying degrees in wood (U.S. Department of Energy, 1998). Trees sequester more $\mathrm{C}$ than shrubs and large trees sequester more $\mathrm{C}$ than small trees. Residential trees also provide other environmental services (McPherson and Simpson, 1999). Kendall and McPherson (2012) reported that 4.6 and $15.3 \mathrm{~kg} \mathrm{CO}_{2} \mathrm{e}$ were emitted in the production and distribution of trees grown in \#5 and \#9 containers, respectively. Their work modeled an intensive container nursery in California and did not include the impact of sequestered $\mathrm{C}$ during production. 
Individual components of production systems result in $\mathrm{GHG}$ emissions to varying degrees. Ingram (2012) reported that a significant contributor to GHG emissions in the field production of red maple was fuel consumption by farm machinery and truck transport of the finished product. That report also estimated the impact of altering certain production system protocols to reduce GHG emissions. GHG emissions have been estimated for various other agricultural production systems (Lal, 2004; West and Marland, 2002a, 2002b).

The purpose of this study was to use LCA to determine the carbon footprint of a 2-m-tall, field-grown, spade-dug Picea pungens (colorado blue spruce) in the lower midwestern and upper midwestern United States (hardiness zones 6a to 7a) and to analyze the contributions of system components. The scope included the production system from seed to the farm gate and from the farm gate to transplanting in a landscape site. The impact of the use phase and end-of-life phase was also assessed.

\section{Methods and Materials}

The functional unit was defined as a field-grown, spade-dug colorado blue spruce with a height of $2 \mathrm{~m}$, caliper of $5 \mathrm{~cm}$, and a 61-cm-diameter soil/root ball with $5.0 \mathrm{~kg}$ plant dry weight. Production and transport protocols for evergreen trees vary widely among nurseries; therefore, a detailed model system was described following interviews with nursery managers in the region. The boundaries for this LCA include a liner produced in a nursery in the upper midwestern United States specializing in propagation and shipped to a field nursery in the lower midwestern United States for production of the finished product (Fig. 1). Seeds would be germinated in ground beds and grown for two years before transplanting them to the field for an

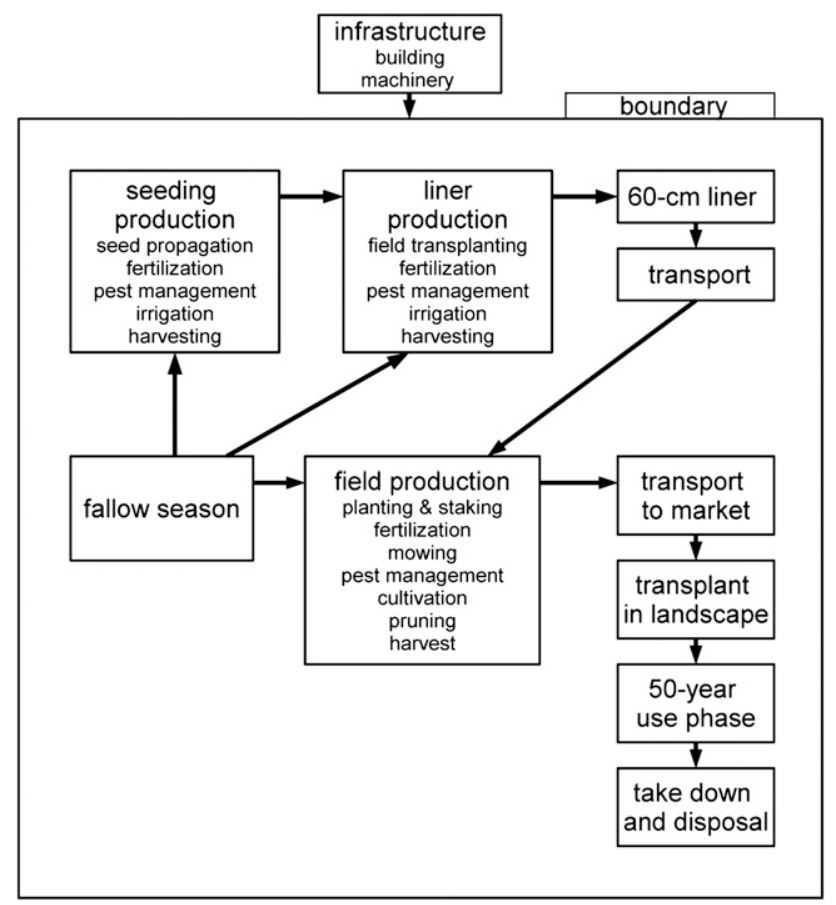

Fig. 1. Input products and process flow diagram and system boundaries for the life cycle of a field-grown, spade-dug, 5-cm-caliper colorado blue spruce in the lower midwestern United States (liner) and upper midwestern United States (finished tree). additional two years in the propagation nursery to produce a 50 - to $60-\mathrm{cm}$-tall liner referred to as a " $2+2$ liner" in the industry. That liner would be transported to a field nursery where it would be transplanted on 1.8-m in-row spacing in rows $2.4 \mathrm{~m}$ apart (2224 plants/ha). The tree would be grown for five years and harvested as a $2-\mathrm{m}$-tall tree using a tree spade mounted on a skid-steer loader. The tree would be transported to a landscape contractor who would transplant it in a suburban site with favorable soil, light, and space conditions. Nowak et al.'s (2002) tree management model reported colorado blue spruce as a long-lived tree with moderate growth rate, based on Fleming (1988) and Nowak (1994), and used a 60-year life span in the landscape. However, conversations with landscape managers indicate a shorter life expectancy. Therefore, it was assumed in this LCA that the tree would live for 50 years at which time it would be removed and chipped into mulch material.

This study was conducted in accordance with the ISO (2006) published standard, and PAS 2050 guidelines by BSI British Standards (2011). The products and equipment used were inventoried and their individual $\mathrm{GHG}$ emissions were determined, converted to kilograms $\mathrm{CO}_{2}$ e per functional unit, and summed. Emissions associated with the manufacturing of capital goods such as buildings and machinery were not included in this study as per PAS 2050, Section 6.4.4 (BSI British Standards, 2011). Labor was assumed to have no direct impact on the carbon footprint of a product. It was assumed that the farms have been in agricultural production for at least 50 years and in nursery production for at least 20 years; therefore, impact of land use change was not included in this study as per PAS 2050.

INPUT MATERIALS AND EQUIPMENT USE IN LINER PRODUCTION. The materials (Table 1) and equipment use (Table 2) for liner production were inventoried based on the model system. Seeds would be collected from a mature stand of uniform trees. Because each cone would yield 350 to 400 seeds, the GWP impact of seed production was determined to be insignificant and not included. The field plot in sandy loam soil would remain fallow for one year with a cover crop of oilseed radish (Raphanus sativus) after chisel plowing and disking. The cover crop would be plowed under in the fall. In the next spring, agricultural lime and potassium as $\mathrm{KCl}$ would be applied as per a soil test assumed in this study to be 2242 and $373 \mathrm{~kg} \cdot \mathrm{ha}^{-1}$, respectively. The entire plot would be disked and fumigated with methyl bromide (MeBr) applied the next spring using soil injection and covered with a $0.024-\mathrm{mm}$-thick, clear, polyethylene tarp. It should be noted that the use of $\mathrm{MeBr}$ is being phased out and is governed by critical-use permits for forest nursery seedling production in several states and has other environmental impact such as oxygen depletion [U.S. Environmental Protection Agency (USEPA), 2012].

Raised beds, $1.1 \mathrm{~m}$ wide, would be shaped between $0.7-\mathrm{m}$ aisles. Seeds would be sown at the rate to yield 215 seedlings $/ \mathrm{m}^{2}$ in beds $182 \mathrm{~m}$ long $\left(200 \mathrm{~m}^{2} / \mathrm{bed}, 30 \mathrm{beds} / \mathrm{ha}\right)$. Seeds and subsequent seedlings would be irrigated up to $1 \mathrm{~h}$ daily through stationary pipe with a $44.7-\mathrm{kW}$, diesel-powered pump, irrigating 1.6 ha at a time. Beds would be fertilized with $19 \mathrm{~N}-0 \mathrm{P}-5.0 \mathrm{~K}$ using ammonium sulfate as the nitrogen $(\mathrm{N})$ source at the rate of $224 \mathrm{~kg} \cdot \mathrm{ha}^{-1} \mathrm{~N}$ per year split into 12 applications during the summer months each year of the seedling production phase. Pesticides would be applied according to the label. A preemergent herbicide, oxyfluorfen (Goal; Dow AgroSciences, 
Table 1. Contribution of material inputs to the carbon footprint [global warming potential (GWP) in kilograms $\mathrm{CO}_{2}$ equivalent $\left.\left(\mathrm{CO}_{2} \mathrm{e}\right)\right]$ for a 60 -cm-tall $(2+2)$ colorado blue spruce liner.

\begin{tabular}{|c|c|c|c|c|}
\hline Input material & $\begin{array}{l}\text { Product } \\
\left(\mathrm{kg} \cdot \mathrm{ha}^{-1}\right)\end{array}$ & $\begin{array}{c}\text { Product per } \\
\text { marketable liner } \\
(\mathrm{g})\end{array}$ & $\begin{array}{c}\text { Product GWP } \\
{\left[\mathrm{CO}_{2} \mathrm{e}\left(\mathrm{kg} \cdot \mathrm{kg}^{-1}\right)\right]}\end{array}$ & $\begin{array}{c}\text { GWP per } \\
\text { marketable liner } \\
\left(\mathrm{kg} \mathrm{CO}_{2} \mathrm{e}\right) \\
\end{array}$ \\
\hline \multicolumn{5}{|l|}{ Seedling production } \\
\hline Oilseed radish & 16.81 & 0.006 & 1.8300 & 0.000010 \\
\hline Ag lime $\left(\mathrm{CaCO}_{3}\right)$ & 2241.72 & 0.725 & 0.5900 & 0.000425 \\
\hline Pre-plant $\mathrm{K}$ as $\mathrm{KCl}$ & 186.06 & 0.060 & 0.8400 & 0.000051 \\
\hline Polyethylene film & 233.81 & 0.079 & 1.5000 & 0.000118 \\
\hline $\mathrm{N}$ as $\left(\mathrm{NH}_{4}\right)_{2} \mathrm{SO}_{4}$ & 273.94 & 0.091 & 7.8500 & 0.000711 \\
\hline $\mathrm{K}$ as $\mathrm{KCl}$ & 71.62 & 0.024 & 0.8400 & 0.000020 \\
\hline \multicolumn{5}{|l|}{ Transplant production } \\
\hline Oilseed radish & 16.81 & 0.059 & 1.8300 & 0.000108 \\
\hline Ag lime $\left(\mathrm{CaCO}_{3}\right)$ & 2241.72 & 7.560 & 0.5900 & 0.004432 \\
\hline Pre-plant $\mathrm{K}$ as $\mathrm{KCl}$ & 186.06 & 0.060 & 0.8400 & 0.000529 \\
\hline $\mathrm{N}$ as $\left(\mathrm{NH}_{4}\right)_{2} \mathrm{SO}_{4}$ & 273.94 & 0.709 & 7.8500 & 0.005564 \\
\hline \multirow[t]{2}{*}{$\mathrm{K}$ as $\mathrm{KCl}$} & 53.72 & 0.186 & 0.8400 & 0.000157 \\
\hline & $\begin{array}{l}\text { Product } \\
\left(\mathrm{kg} \cdot \mathrm{ha}^{-1}\right)\end{array}$ & $\begin{array}{c}\text { Active } \\
\text { ingredient per } \\
\text { marketable liner } \\
(\mathrm{g})\end{array}$ & $\begin{array}{c}\text { Product GWP } \\
{\left[\mathrm{CO}_{2} \mathrm{e}\left(\mathrm{kg} \cdot \mathrm{kg}^{-1} \text { a.i. }\right)\right]}\end{array}$ & $\begin{array}{c}\text { GWP per } \\
\text { marketable liner } \\
\left(\mathrm{kg} \mathrm{CO}_{2} \mathrm{e}\right) \\
\end{array}$ \\
\hline \multicolumn{5}{|l|}{ Seedling production } \\
\hline Methyl bromide & 392.30 & 0.1322 & 1.8530 & 0.000245 \\
\hline Oxyfluorfen & 5.60 & 0.0004 & 23.0832 & 0.000009 \\
\hline Chlorothalonil & 24.65 & 0.0067 & 14.2896 & 0.000096 \\
\hline Imidacloprid & 0.88 & 0.0002 & 18.6864 & 0.000003 \\
\hline \multicolumn{5}{|l|}{ Transplant production } \\
\hline Chlorothalonil & 24.65 & 0.0234 & 14.2896 & 0.000334 \\
\hline Imidacloprid & 0.88 & 0.0018 & 18.6864 & 0.000034 \\
\hline Flumioxazin & 1.05 & 0.0019 & 23.0832 & 0.000043 \\
\hline
\end{tabular}

$\mathrm{K}=$ potassium; $\mathrm{N}=$ nitrogen.

Indianapolis, IN), would be applied twice over two growing seasons. A fungicide, chlorothalonil (Bravo Ultrex; Syngenta Crop Protection, Greensboro, NC), would be applied six times per year and an insecticide, imidacloprid (Marathon; OHP, Mainland, PA), would be applied one time per year. Plants would be harvested in the fall of the second growing season with a tractor with a tree lifter, placed in a cooler for grading and sorting, and planted at a wider spacing in prepared beds within $2 \mathrm{~d}$. A 35\% cull rate would be assumed at this stage.

The field plot to receive the two-year-old seedlings would have been fallowed and prepared as described previously but would not be fumigated. Seedlings would be mechanically transplanted in the raised beds prepared as previously described at a spacing of $8.9 \mathrm{~cm}$ within rows $28 \mathrm{~cm}$ apart (12,000 per bed) and grown for two years. These beds would be fertilized as described previously except the rate would be decreased to $112 \mathrm{~kg} \cdot \mathrm{ha}^{-1} \mathrm{~N}$ per year the second year of the transplant production phase. A pre-emergent herbicide, flumioxazin (Surguard; Valent U.S.A., Walnut Creek, CA), would be applied three times over the two years; a fungicide, chlorothalonil (Bravo Ultrex), would be applied two times per year; and an insecticide, imidacloprid (Marathon), would be applied once per year. Plants would be harvested in early spring after the second growing season using a tractor with a tree lifter. The plants would be transported to a barn or cooler, sorted, and stored for $\approx 1$ week before shipping to the field nursery. A $20 \%$ cull rate would be expected in this phase. It was assumed based on nursery manager interviews that 60,000 transplants would be shipped $482 \mathrm{~km}$ to the field nursery in a tractor/trailer transporter.

INPUT MATERIALS AND EQUIPMENT USE IN FIELD NURSERY PRODUCTION. Based on the model system, the materials (Table 3 ) and equipment use (Table 4) for field production of the finished product were inventoried. A fallow year with a cover crop, sudex (Sorghum bicolor $\times$ S. sudanense), was assumed. Land preparation would include sub-soiling and disking before seeding. The sudex would be turned under the fall of the fallow year. Agricultural lime would be applied and the field would be disked. Fertilizer $(28 \mathrm{~N}-$ $3.0 \mathrm{P}-11.6 \mathrm{~K}$, urea as the $\mathrm{N}$ source) would be banded in rows manually each year. Pesticides would be applied according to the label. A preemergent herbicide, prodiamine (Baracade; Syngenta Crop Protection), would be banded in-row in the spring annually the first two growing seasons. Glyphosate (Roundup Pro; Monsanto, St. Louis, MO) would be applied in-row as a directed spray three times per year. Carbonyl (Sevin; Bayer Environmental Science, Triangle Park, NC) would be applied as needed for control of bagworm (Thyridopteryx ephemeraeformis). It was assumed that $12.5 \%$ of the plants would be sprayed annually for bagworm with a backpack sprayer. Plants would be irrigated twice during the first year using a tractor, wagon, water tank, and a $3.7-\mathrm{kW}$ gasoline water pump allowing for individual tree watering. The between-row space would be mowed four times per year. The finished product would be dug with a $61-\mathrm{cm}$ tree spade mounted on a skid-steer loader and hauled to the shipping area with a tractor and wagon. A skid-steer loader with an articulating arm would be used to load wagons in the field and to load trucks for delivery. Culls (10\% of crop) would be removed with a bulldozer.

Assumptions in POST-HARVEST aCtIVITIES. GHG emissions for transporting the finished trees to a landscape contractor were based on fuel consumption $\left(2.55 \mathrm{~km} \cdot \mathrm{L}^{-1}\right)$ for 120 trees moving $241 \mathrm{~km}$ in a heavy truck and trailer. Ten percent of the load per tree of a light truck and trailer $\left(4.3 \mathrm{~km} \cdot \mathrm{L}^{-1}\right)$ would transport the tree to a landscape site. Traveling distance was established through interviews with nursery managers and landscape contractors. Five minutes of a $26.1-\mathrm{kW}$ tractor with a bucket was assumed for moving the tree from the trailer to the planting hole. The tree would be planted by hand. Based on interviews with certified arborists, it was assumed that takedown and disposal of the tree after its useful life would use a heavy truck traveling $40 \mathrm{~km}$, a chainsaw for $2 \mathrm{~h}$, and a 104.4-kW chipper for $1 \mathrm{~h}$. The resulting material would be used for mulch.

ASSUMPTIONS FOR EQUIPMENT USE. Motorized machinery would be used in the activities described previously. Tractors 
Table 2. Contribution of equipment use to the carbon footprint [global warming potential (GWP) in kilograms $\mathrm{CO}_{2}$ equivalent $\left.\left(\mathrm{CO}_{2} \mathrm{e}\right)\right]$ for a $60-\mathrm{cm}(2+2)$ colorado blue spruce liner. ${ }^{\mathrm{z}}$

\begin{tabular}{|c|c|c|c|c|}
\hline Equipment use & $\begin{array}{l}\text { Use time } \\
\left(\mathrm{h} \cdot \mathrm{ha}^{-1}\right)\end{array}$ & $\begin{array}{c}\text { Time per } \\
\text { marketable liner } \\
\left(10^{-4} \mathrm{~h}\right) \\
\end{array}$ & $\begin{array}{c}\text { Fuel per } \\
\text { marketable liner } \\
(\mathrm{mL}) \\
\end{array}$ & $\begin{array}{c}\text { GWP per } \\
\text { marketable liner } \\
\left(\mathrm{kg} \mathrm{CO}_{2} \mathrm{e}\right) \\
\end{array}$ \\
\hline \multicolumn{5}{|c|}{ Each fallow year: seedling and transplant production fields } \\
\hline Chisel plow & 3.74 & 0.012 & 0.015 & 0.000044 \\
\hline Disking & 1.25 & 0.004 & 0.005 & 0.000015 \\
\hline Cover crop seeding & 1.25 & 0.004 & 0.005 & 0.000015 \\
\hline Dragging & 1.25 & 0.004 & 0.005 & 0.000015 \\
\hline Turning plow & 3.74 & 0.012 & 0.015 & 0.000044 \\
\hline \multicolumn{5}{|l|}{ Seedling production } \\
\hline Broadcast ag lime $\left(\mathrm{CaCO}_{3}\right)$ & 1.25 & 0.004 & 0.005 & 0.000015 \\
\hline Broadcast $\mathrm{KCl}$ & 1.25 & 0.004 & 0.005 & 0.000015 \\
\hline Disking & 1.25 & 0.004 & 0.005 & 0.000015 \\
\hline Fumigation & 1.05 & 0.003 & 0.004 & 0.000012 \\
\hline Plastic tarp removal & 1.25 & 0.043 & 0.027 & 0.000082 \\
\hline Bed shaping & 2.24 & 0.007 & 0.009 & 0.000027 \\
\hline Sow seed & 2.24 & 0.007 & 0.005 & 0.000014 \\
\hline Broadcast fertilizer & 14.93 & 0.050 & 0.047 & 0.000141 \\
\hline Irrigation & 121.90 & 0.407 & 0.517 & 0.001562 \\
\hline Herbicide application & 0.75 & 0.003 & 0.002 & 0.000007 \\
\hline Fungicide application & 4.52 & 0.015 & 0.014 & 0.000043 \\
\hline Insecticide application & 0.75 & 0.026 & 0.002 & 0.000007 \\
\hline Harvest from bed & 29.90 & 0.100 & 0.190 & 0.000574 \\
\hline Transport from field & 7.47 & 0.025 & 0.016 & 0.000047 \\
\hline \multicolumn{5}{|l|}{ Transplant production } \\
\hline Broadcast ag lime $\left(\mathrm{CaCO}_{3}\right)$ & 1.25 & 0.043 & 0.051 & 0.000154 \\
\hline Broadcast $\mathrm{KCl}$ & 1.25 & 0.043 & 0.051 & 0.000154 \\
\hline Disking & 1.25 & 0.043 & 0.051 & 0.000154 \\
\hline Bed shaping & 2.24 & 0.078 & 0.092 & 0.000277 \\
\hline Transplant seedlings & 13.59 & 0.473 & 0.556 & 0.001681 \\
\hline Broadcast fertilizer & 11.19 & 0.390 & 0.364 & 0.001102 \\
\hline Irrigation & 46.02 & 1.603 & 2.035 & 0.006144 \\
\hline Herbicide application & 1.13 & 0.039 & 0.204 & 0.000111 \\
\hline Fungicide application & 1.51 & 0.052 & 0.049 & 0.000148 \\
\hline Insecticide application & 0.75 & 0.026 & 0.024 & 0.000074 \\
\hline Harvest from bed & 29.90 & 1.042 & 1.983 & 0.005989 \\
\hline Transport from field & 14.95 & 0.521 & 0.324 & 0.000982 \\
\hline Transport to field nursery & $\mathrm{NA}^{\mathrm{y}}$ & NA & 2.629 & 0.007928 \\
\hline
\end{tabular}

${ }^{\mathrm{z}}$ Well-to-wheel GWP of diesel fuel was assumed to be $3.01526 \mathrm{~kg} \mathrm{CO}_{2} \mathrm{e}$ per liter of fuel as per GREET1_2011 (Vyas and Singh, 2011).

yot applicable.

with a specified power rating (kilowatts) would be matched to each operation. The portion of maximum tractor throttle and load for each operation was assumed to be: land preparation, $44.7-\mathrm{kW}$ tractor at 0.85 throttle and 0.85 load; spraying and spreading in the liner nursery, high-clearance $67.1-\mathrm{kW}$ tractor at 0.50 throttle and 0.50 load; transporting the plants from the field to the cooler/barn, $44.7-\mathrm{kW}$ tractor at 0.50 throttle and 0.50 load; mowing, $17.9-\mathrm{kW}$ tractor at 0.85 throttle and 0.85 load; liner harvesting, $67.1-\mathrm{kW}$ tractor at 1.0 throttle and 0.85 load; and harvesting finished trees, 55.9-kW skid-steer loader with tree spade at 1.0 throttle and 0.85 load. The fuel consumption of a $44.7-\mathrm{kW}$ diesel irrigation pump was assumed to equal that of a tractor at 1.0 throttle and 0.85 load. The fuel consumption for the $3.7-\mathrm{kW}$ irrigation pump was assumed to be $1.9 \mathrm{~L} \cdot \mathrm{h}^{-1}$. The 104.4-kW chipper was assumed to consume diesel at the rate of a $104.4-\mathrm{kW}$ tractor at 1.0 throttle and 0.85 load.
INVENTORY ANALYSIS AND DATA COLLECTION. The GWP of input materials was determined as follows. The average $\mathrm{C}$ emission equivalent for a range of herbicides, insecticides, and fungicides was estimated by Lal (2004) to be $6.3 \pm 2.7,5.1 \pm$ 3.0 , and $3.9 \pm 2.2 \mathrm{~kg} \mathrm{C}$-equivalent per kilogram a.i., respectively. Lal also reported $\mathrm{C}$ emission equivalents for specific pesticides as 9.1 and $3.1 \mathrm{~kg} \mathrm{C}$ equivalent per kilogram of glyphosate and carbaryl, respectively. These $\mathrm{C}$ emissions were converted to $\mathrm{CO}_{2}$ equivalent by multiplying by 3.664 . The GWP of $\mathrm{MeBr}$ is 5.0, meaning it has five times the GWP as $\mathrm{CO}_{2}$ (USEPA, 2010). According to the Montreal Protocol, $0.203 \mathrm{~kg} \mathrm{CO}_{2} \mathrm{e}$ would be invested in the production and distribution of each kilogram of $\mathrm{MeBr}$ (United Nations, 1987). Based on the Montreal Protocol, it was assumed that $33 \%$ of soil-applied MeBr would be lost directly to the environment as a result of application processes, which would add another $1.65 \mathrm{~kg}$ $\mathrm{CO}_{2} \mathrm{e}$ to the GWP of each kilogram of $\mathrm{MeBr}$. Therefore, the GWP was assumed to be $1.853 \mathrm{~kg} \mathrm{CO}_{2}$ e per kilogram of $\mathrm{MeBr}$.

Snyder et al. (2009) calculated from the U.S. Department of Energy's Greenhouse Gases, Regulated Emissions, and Energy Use in Transportation model, GREET 1.8a (Wang, 2007), that the GWP for manufacturing and transporting $\mathrm{N}$ (from urea), phosphorus, potassium, and lime to be $3.2,2.3,0.84$, and $0.6 \mathrm{~kg}$ $\mathrm{CO}_{2} \mathrm{e}$ per kilogram of material, respectively. It was assumed that the GWP of ammonium sulfate was similar to that of urea, although it is a byproduct of industrial process and may have a smaller carbon footprint in some regions. Although highly variable, an additional GWP for fertilizer-induced $\mathrm{N}_{2} \mathrm{O}$ emission from soils was calculated to be $4.65 \mathrm{~kg} \mathrm{CO}_{2} \mathrm{e}$ per kilogram $\mathrm{N}$ applied, assuming a $1 \%$ direct loss of applied $\mathrm{N}$ as $\mathrm{N}_{2} \mathrm{O}$ (IPCC, 2006; Snyder et al., 2009). Lal (2004) reported a mean $\mathrm{C}$ emission from the production, transportation, storage, and transfer of agricultural lime to be $0.160 \pm 0.11 \mathrm{~kg} \mathrm{C}$, indicating the variability of this product and its associated GWP.

GWP for machinery and truck use in each operation was estimated based on fuel consumption calculations. Diesel consumption for tractors and the irrigation pump was estimated using the American Society for Agricultural and Biological Engineers' Standard published in 2009 and applied in a Virginia Cooperative Extension Service publication (Grisso et al., 2010) adjusting for expected load and throttle for each operation for each tractor. Diesel consumption rates used for heavy trucks 
Table 3. Contribution of material inputs to the carbon footprint [global warming potential (GWP) in kilograms $\mathrm{CO}_{2}$ equivalent $\left(\mathrm{CO}_{2} \mathrm{e}\right)$ ] for a 2-m-tall colorado blue spruce assuming a five-year field production cycle.

\begin{tabular}{|c|c|c|c|c|}
\hline Input material & $\begin{array}{l}\text { Product } \\
\left(\mathrm{kg} \cdot \mathrm{ha}^{-1}\right)\end{array}$ & $\begin{array}{c}\text { Product per } \\
\text { marketable tree } \\
(\mathrm{kg})\end{array}$ & $\begin{array}{c}\text { Product GWP } \\
{\left[\mathrm{CO}_{2} \mathrm{e}\left(\mathrm{kg} \cdot \mathrm{kg}^{-1}\right)\right]}\end{array}$ & $\begin{array}{c}\text { GWP per } \\
\text { marketable tree } \\
\left(\mathrm{kg} \mathrm{CO}_{2} \mathrm{e}\right) \\
\end{array}$ \\
\hline Sudex seed & 44.83 & 0.0224 & 4.067 & 0.091 \\
\hline Ag lime $\left(\mathrm{CaCO}_{3}\right)$ & 2241.72 & 1.1200 & 0.590 & 0.656 \\
\hline Nitrogen & 364.74 & 0.1822 & 7.850 & 1.430 \\
\hline Phosphorus & 39.71 & 0.0198 & 2.300 & 0.045 \\
\hline Potassium & 151.37 & 0.0756 & 0.840 & 0.064 \\
\hline Wire basket (count) & 2002 & 0.6520 & 1.293 & 0.843 \\
\hline $\begin{array}{l}\text { Cardboard truck } \\
\text { protector (count) }\end{array}$ & 2002 & 0.0113 & 0.470 & 0.005 \\
\hline \multirow[t]{2}{*}{ Transplant (count) } & 2224 & 1.1111 & 0.043 & 0.048 \\
\hline & $\begin{array}{l}\text { Product } \\
\left(\mathrm{kg} \cdot \mathrm{ha}^{-1}\right)\end{array}$ & $\begin{array}{c}\text { Active } \\
\text { ingredient per } \\
\text { marketable tree } \\
(\mathrm{kg})\end{array}$ & $\begin{array}{c}\text { Product GWP } \\
{\left[\mathrm{CO}_{2} \mathrm{e}\left(\mathrm{kg} \cdot \mathrm{kg}^{-1} \mathrm{a} \text {.i. }\right)\right]}\end{array}$ & $\begin{array}{c}\text { GWP per } \\
\text { marketable tree } \\
\left(\mathrm{kg} \mathrm{CO}_{2} \mathrm{e}\right)\end{array}$ \\
\hline Prodiamine & 1.67 & 0.0005 & 23.083 & 0.012 \\
\hline Glyphosate & 39.43 & 0.0081 & 33.342 & 0.270 \\
\hline Carbonyl & 0.89 & 0.0002 & 11.358 & 0.002 \\
\hline
\end{tabular}

Table 4. Contribution of equipment use to the carbon footprint [global warming potential (GWP) in kilograms $\mathrm{CO}_{2}$ equivalent $\left(\mathrm{CO}_{2} \mathrm{e}\right)$ ] for a 2-m-tall colorado blue spruce assuming a five-year field production cycle. $^{\mathrm{z}}$

\begin{tabular}{lrccc}
\hline & $\begin{array}{c}\text { Time per } \\
\text { Ese time } \\
\left(\mathrm{h} \cdot \mathrm{ha}^{-1}\right)\end{array}$ & $\begin{array}{c}\text { Fuel per } \\
\text { marketable tree } \\
(\mathrm{h})\end{array}$ & $\begin{array}{c}\text { GWP per } \\
\text { marketable tree } \\
(\mathrm{L})\end{array}$ & $\begin{array}{c}\text { marketable tree } \\
\left(\mathrm{kg} \mathrm{CO}_{2}\right)\end{array}$ \\
\hline Subsoiling & 1.85 & 0.0009 & 0.014 & 0.044 \\
Disking & 1.24 & 0.0006 & 0.005 & 0.016 \\
Cover crop seeding & 3.21 & 0.0016 & 0.025 & 0.076 \\
Dragging & 1.24 & 0.0006 & 0.005 & 0.015 \\
Turning plow & 1.85 & 0.0009 & 0.014 & 0.044 \\
Spread ag lime $\left(\mathrm{CaCO}_{3}\right)$ & 1.24 & 0.0006 & 0.010 & 0.029 \\
Disking & 1.24 & 0.0006 & 0.005 & 0.015 \\
Transplanting & 7.41 & 0.0037 & 0.031 & 0.093 \\
Herbicide application & 23.48 & 0.0117 & 0.029 & 0.089 \\
Mow & 24.71 & 0.0123 & 0.058 & 0.176 \\
Irrigation (twice) & 47.43 & 0.0237 & 0.083 & 0.252 \\
Digging with tree spade & 166.80 & 0.0833 & 1.322 & 4.014 \\
Loading on wagon & 100.08 & 0.0500 & 0.734 & 2.159 \\
Hauling from field & 166.80 & 0.0833 & 1.410 & 4.144 \\
Loading on truck & 66.72 & 0.0333 & 0.490 & 1.439 \\
Removal of culls & 18.53 & 0.00939 & 0.157 & 0.463 \\
\hline
\end{tabular}

${ }^{\mathrm{z}}$ Well-to-wheel GWP of diesel fuel assumed to be $3.01526 \mathrm{~kg} \mathrm{CO}_{2} \mathrm{e}$ per liter of fuel as per GREET1_2011 (Vyas and Singh, 2011).

and light trucks were assumed to be 6 and $4.2 \mathrm{~km} \cdot \mathrm{L}^{-1}$, respectively. The GWP factors for fuel consumption were determined based on "well-to-wheel" emission reported in GREET1_2011 (Vyas and Singh, 2011) as $2.93389 \mathrm{~kg} \mathrm{CO}_{2} \mathrm{e}$ per liter for gasoline and $3.01526 \mathrm{~kg} \mathrm{CO}$ e per liter for diesel. The GWP of fluids used by tractors during a 10,000-h life was calculated using GREET2_7 "Vehicle Fluids" (Burnham et al., 2006) for consumption and disposal of engine oil (changed every $1000 \mathrm{~h}$ ), power steering fluid (changed one time), brake fluid (changed one time), transmission fluid (changed two times), and coolant (changed two times). The fluid GWP for the chipper and irrigation pump engines assumed changing only engine oil and coolant and following the same frequency as for tractors. Fluid use by trucks was calculated based on general recommendations for fluidchanging schedules.

The GWP of oilseed radish seeds or sudex seeds could not be found. However, the reported GWPs of seed production for wheat (Triticum aestivum) and rapeseed (Brassica napus) were 1.5 and $1.84 \mathrm{~kg} \mathrm{CO}_{2} \mathrm{e}$ per kilogram, respectively (U.S. Department of Energy, 2012). West and Marland (2002b) reported GWPs for orchardgrass (Dactylis glomerata) seeds (1.11 kg $\mathrm{CO}_{2} \mathrm{e}$ per kilogram) and ryegrass (Lolium perenne) seeds $\left(0.54 \mathrm{~kg} \mathrm{CO}_{2} \mathrm{e}\right.$ per kilogram). Therefore, this study assumed GWPs of 1.84 and $1.11 \mathrm{~kg} \mathrm{CO}_{2}$ e per kilogram of oilseed radish and sudex seeds, respectively.

Based on a professional LCA conducted for the World Steel Association (Brussels, Belgium) (unpublished data) for the steel wire from recycled steel, the GWP of the wire basket was assumed to be $1.2927 \mathrm{~kg} \mathrm{CO}$ e per kilogram. Although $0.638 \mathrm{~kg}$ of burlap and $0.045 \mathrm{~kg}$ of nylon twine were used in packaging the harvested tree, the GWP for these products was not readily available and considered to have a negligible impact.

The annual GWP overhead for the liner nursery and the field nursery was determined by estimating the electricity (shop, cooler, office, etc.) and gasoline use (all-terrain vehicle, small tractor, farm truck, chain saw, etc.) in general farm operations. It was assumed that a 42-ha liner nursery would consume $55,000 \mathrm{~kW}-\mathrm{h}$ per year in electricity and $5148 \mathrm{~L}$ per year of gasoline for general operations. A 71-ha field nursery was assumed to consume $14,150 \mathrm{~kW}$-h per year of electricity and $1453 \mathrm{~L}$ per year of gasoline. The GWP of electricity was assumed to be $0.67 \mathrm{~kg} \mathrm{CO}_{2}$ e per $\mathrm{kW}$-h (Samaras and Meisterling, 2008).

LCAs of farming operations should consider the carbon captured by the growth of the crop (Mourad et al., 2007), especially for perennial crops. It was assumed that $50 \%$ of the tree dry weight was C (McPherson and Simpson, 1999), which was multiplied by 3.664 to yield the kilogram $\mathrm{CO}_{2}$ sequestered during production.

Carbon is sequestered by trees as they mature during their use phase (McPherson and Simpson, 1999) according to a 
normal growth model for each species. A colorado blue spruce transplanted as a 2-m tall tree into a suburban landscape in the lower midwestern United States, according to the U.S. Forest Service's Center for Urban Forestry Research (CUFR) Tree Carbon Calculator calculation method (U.S. Department of Agriculture, 2008), would sequester $2093 \mathrm{~kg} \mathrm{CO}_{2}$ aboveground and in the roots in 50 years. The rate of $\mathrm{C}$ sequestered differs over time as per a normal growth curve and not all the carbon would be sequestered for the full 50 years of useful life. The assumed 50 years of useful life is also less than the 100-year assessment period specified by international standards (BSI British Standards, 2011). Using the growth curve for colorado blue spruce in the CUFR Tree Carbon Calculator and the protocol for estimating the weighted average GWP impact of stored C described in Appendix E of PAS 2050 (BSI British Standards, 2011), the annual sequestration relative to a portion of the 100-year assessment period was calculated. This protocol accounts for the fact that $\mathrm{CO}_{2}$ sequestered in Year 1 would be stored throughout the 50-year life of the use phase but the $\mathrm{CO}_{2}$ sequestered in Year 40 would be stored for only 10 years of the 100-year assessment period. It was assumed that the tree would be removed from the landscape after 50 years and stored $\mathrm{C}$ in the truck, shoots, and roots would be released into the atmosphere relatively quickly. Although storage of carbon sequestered in roots has been reported to reside in the rhizosphere for an extended period after tree removal (IPCC, 2006; McPherson and Simpson, 1999; Mokany et al., 2006), this was not considered as a result of the lack of definitive data for spruce in the lower midwestern United States. It should be noted that $\mathrm{CO}_{2}$ emission reduction resulting from energy savings in a building resulting from a strategically placed tree was not included in this study. Carbon investment in tree maintenance in a residential landscape would be expected to be minimal and excluded from this model.

The relative impact of input variables on total $\mathrm{CO}_{2} \mathrm{e}$ investment in a spruce tree life cycle was determined using sensitivity analysis. Each input variable within each life phase was in turn increased by $10 \%$, whereas other variables were unchanged in model simulations. The maximum percentage change in total kilograms $\mathrm{CO}_{2} \mathrm{e}$ investment in the tree was used to assess the sensitivity of the model to each variable. The sensitivity of $\mathrm{CO}_{2}$ sequestration during production, use, and end-of-life phases was calculated separately using the same procedures. Sensitivity for each phase was expressed relative to the final carbon footprint.

\section{Results and Discussion}

The estimated seed-to-landscape carbon footprint of a 2-m-tall, 5-cm caliper colorado blue spruce tree produced in the upper midwestern (liner) and lower midwestern United States (finished tree) was $13.558 \mathrm{~kg} \mathrm{CO}$ e. This included sequestration of $9.14 \mathrm{~kg} \mathrm{CO}_{2} \mathrm{e}$ during production. The total $\mathrm{CO}_{2} \mathrm{e}$ emissions invested in input materials, equipment use, and truck transportation in the production and distribution system in this model was $22.693 \mathrm{~kg} \mathrm{CO}_{2} \mathrm{e}$. These values are somewhat higher than those published for red maple: $8.213 \mathrm{~kg} \mathrm{CO}_{2} \mathrm{e}$ carbon footprint from $12.1 \mathrm{~kg} \mathrm{CO}_{2}$ sequestered during production and $20.567 \mathrm{~kg} \mathrm{CO}_{2} \mathrm{e}$ total GWP investment in production and distribution (Ingram, 2012). These differences can partially be explained by the more rapid growth rate and larger mass of the red maple compared with the spruce offset by the two years additional for liner production at a higher population density and one year additional required in field production for the spruce.

The carbon footprint of the liner at the farm gate was $0.035 \mathrm{~kg} \mathrm{CO}_{2} \mathrm{e}$, including $0.001 \mathrm{~kg} \mathrm{CO}_{2} \mathrm{e}$ from overhead GWP (electricity and non-assigned fuel consumption) of the liner nursery. This did not account for sequestration of $\mathrm{C}$ at this stage of production. An additional $0.008 \mathrm{~kg} \mathrm{CO}_{2} \mathrm{e}$ was invested in transporting the liner $483 \mathrm{~km}$ to the field nursery. The GWP of input materials and equipment use contributed 0.013 and $0.021 \mathrm{~kg} \mathrm{CO} 2 \mathrm{e}$, respectively, to the liner carbon footprint (Table 1). Lime and fertilizer contributed $0.012 \mathrm{~kg} \mathrm{CO}_{2} \mathrm{e}$ to GHG emissions from materials, which was 34\% of the liner carbon footprint at the farm gate. Pesticides contributed $0.0008 \mathrm{~kg} \mathrm{CO}_{2} \mathrm{e}$, which was only $2 \%$ of the liner production GWP.

Equipment use in liner production contributed almost half of the liner carbon footprint (Table 2). Among the operations involving equipment use that contributed the most to the carbon footprint included irrigation $\left(0.008 \mathrm{~kg} \mathrm{CO}_{2} \mathrm{e}\right)$, transplanting seedlings $\left(0.002 \mathrm{~kg} \mathrm{CO}_{2} \mathrm{e}\right)$, harvesting the finished liner $(0.006 \mathrm{~kg} \mathrm{CO} 2 \mathrm{e})$, and broadcasting fertilizer $\left(0.001 \mathrm{~kg} \mathrm{CO}_{2} \mathrm{e}\right)$. Although the input materials and equipment use per hectare were similar for the seedling production and transplant production phases for the liner, the lower density of plants and lower cull rate in the transplant production phase compared with the seedling phase resulted in greater GWP impact of materials and equipment use per marketable liner.

When the combined GWP of input materials and equipment use was segregated by production system component for the liner production in the propagation nursery, similar $\mathrm{CO}_{2} \mathrm{e}$ emissions were invested in land preparation and planting, fertilization, irrigation, harvesting, and transportation to the field nursery and combined to account for $97 \%$ of the emissions (Fig. 2). Disease, weed, and insect management contributed $3 \%$ of total GWP.

The total production system GHG emissions from material inputs, from seed to finished tree, contributed $3.467 \mathrm{~kg} \mathrm{CO}_{2} \mathrm{e}$ (Table 3$)$. The GWP of the liner $\left(0.048 \mathrm{~kg} \mathrm{CO}_{2} \mathrm{e}\right)$ contributed

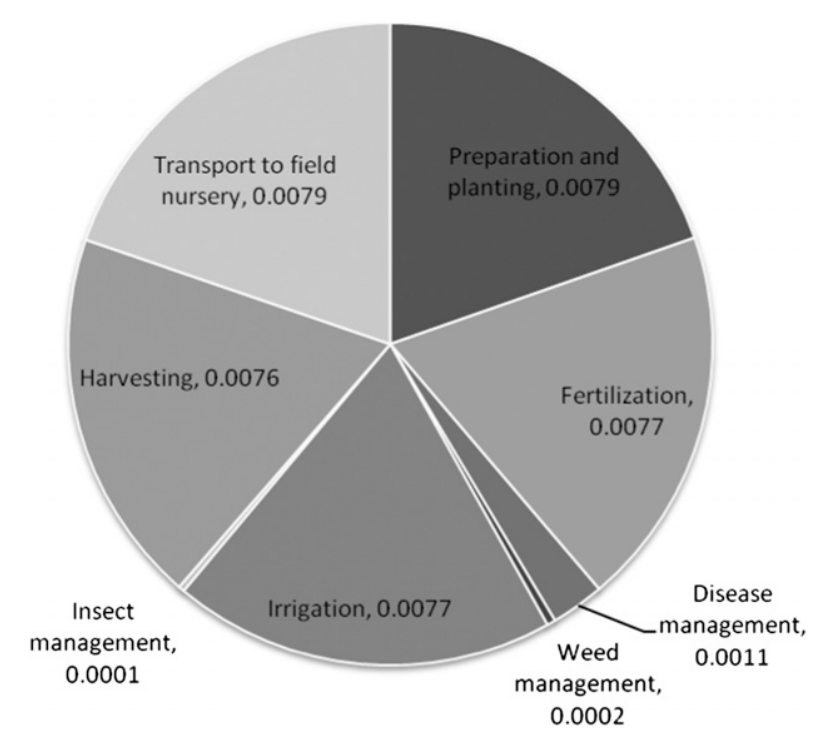

Fig. 2. Material and equipment use contributions of production system components to the carbon footprint (global warming potential in kilograms $\mathrm{CO}_{2}$ equivalent) for a 60 -cm-tall $(2+2)$ colorado blue spruce liner. 
only $0.28 \%$ to the GWP invested in production of the finished tree at the farm gate. Fertilizer and lime contributed $2.196 \mathrm{~kg} \mathrm{CO}_{2} \mathrm{e}, 63 \%$ of the input material GWP. The wire basket and cardboard trunk protector contributed $0.848 \mathrm{~kg} \mathrm{CO}_{2} \mathrm{e}$, $24 \%$ of input materials' GWP impact. Pesticides contributed $0.284 \mathrm{~kg} \mathrm{CO}_{2} \mathrm{e}, 8 \%$ of material GWP investments.

Equipment use in the field nursery contributed $13.069 \mathrm{~kg} \mathrm{CO}_{2} \mathrm{e}$ to total GWP investments (Table 4), $89 \%$ of which occurred at harvest. This value is greater than that published for red maple (8.979 $\left.\mathrm{kg} \mathrm{CO}_{2} \mathrm{e}\right)$. Much of that difference is because this study used a more inclusive value for fuel GWP from GREET, well to wheel (Vyas and Singh, 2011), whereas the red maple study used the USEPA (2005) value for GWP only from the combustion of fuels. The well-to-wheel GWP of diesel was 13\% greater than the more narrowly defined GWP by the USEPA (2005). There was also less GWP invested in staking and pruning in spruce compared with red maple production. The field nursery overhead GWP from energy use not assigned to individual production components was estimated to be $0.581 \mathrm{~kg} \mathrm{CO}_{2} \mathrm{e}$ per tree. Other larger contributors included land preparation $\left(0.239 \mathrm{~kg} \mathrm{CO}_{2} \mathrm{e}\right)$, mowing $\left(0.176 \mathrm{~kg} \mathrm{CO}_{2} \mathrm{e}\right)$, transplanting $\left(0.093 \mathrm{~kg} \mathrm{CO}_{2} \mathrm{e}\right)$, and irrigation $\left(0.252 \mathrm{~kg} \mathrm{CO}_{2} \mathrm{e}\right)$. Equipment use contributed 3.8 times more to the farm-gate carbon footprint than input materials. Direct energy use was the largest component of the published carbon footprint of container-grown trees (Kendall and McPherson, 2012).

When the combined GWP of input materials and equipment use was segregated by operational component in the field production system, harvesting contributed $13.068 \mathrm{~kg} \mathrm{CO}_{2} \mathrm{e}$ to the GWP investment (Fig. 3). That is $76 \%$ of the total GWP investment at the farm gate. Fertilization $\left(1.540 \mathrm{~kg} \mathrm{CO}_{2} \mathrm{e}\right)$, weed management $\left(0.546 \mathrm{~kg} \mathrm{CO}_{2} \mathrm{e}\right)$, and land preparation $\left(0.987 \mathrm{~kg} \mathrm{CO}_{2} \mathrm{e}\right)$ contributed another $18 \%$.

Trees impact the environment by taking up atmospheric $\mathrm{CO}_{2}$ and storing it as $\mathrm{C}$ in wood. Many factors affect how much $\mathrm{C}$ is sequestered during the useful life of a tree. The weighted positive impact of $\mathrm{C}$ storage of a colorado blue spruce over a 50-year useful life in a 100-year assessment period was

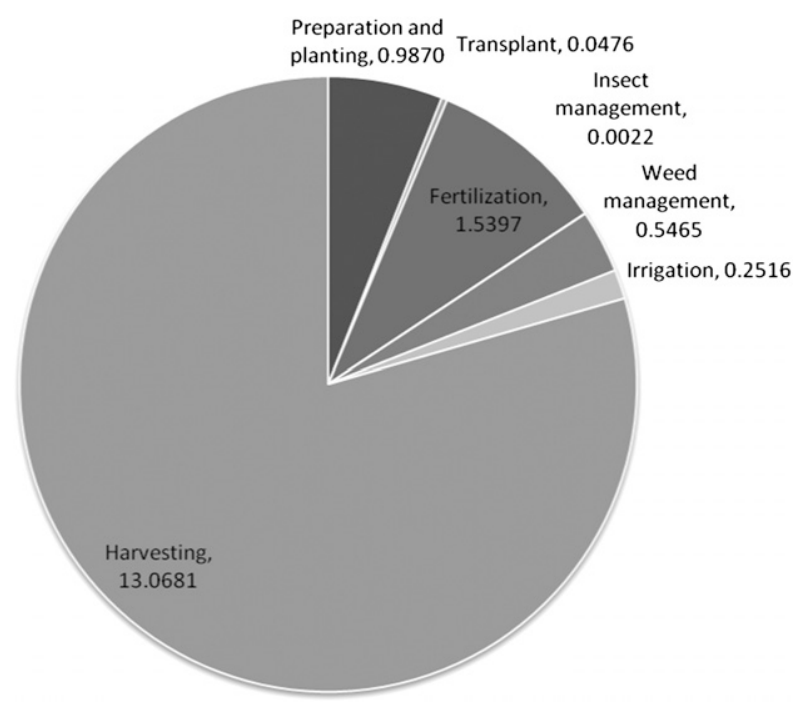

Fig. 3. Material and equipment use contributions of field production system components to the carbon footprint (global warming potential in kilograms $\mathrm{CO}_{2}$ equivalent) for a 2-m-tall, spade-dug colorado blue spruce in a five-year production cycle. calculated as $593 \mathrm{~kg} \mathrm{CO}_{2}$ e. Eighty-seven percent of the direct positive impact on atmospheric $\mathrm{CO}_{2}$ of the tree in the landscape was estimated to occur in the first 40 years. If the assumed life expectancy had been decreased by 10 to 40 years, the weighted impact of $\mathrm{C}$ storage would have been $78 \mathrm{~kg} \mathrm{CO}_{2} \mathrm{e}$ less. An assumed useful life of 60 years would have increased the positive impact by $20 \mathrm{~kg} \mathrm{CO}_{2} \mathrm{e}$. At the conclusion of its useful life, takedown and disposal would result in emissions of $148 \mathrm{~kg} \mathrm{CO}_{2} \mathrm{e}$. Therefore, the net positive impact through the reduction of atmospheric $\mathrm{CO}_{2}$ during the 50 -year use and endof-life phases would be $\approx 446 \mathrm{~kg} \mathrm{CO}_{2} \mathrm{e}$. Subtracting the seed-tolandscape carbon footprint $\left(13.693 \mathrm{~kg} \mathrm{CO}_{2} \mathrm{e}\right)$ yielded an overall positive impact of the colorado blue spruce over its complete life cycle that exceeded $431 \mathrm{~kg} \mathrm{CO}_{2} \mathrm{e}$. That was almost 30 times greater than the seed-to-landscape carbon footprint of the tree. The overall positive life cycle impact after 60 years in the landscape for a red maple was reported to exceed $800 \mathrm{~kg} \mathrm{CO}_{2} \mathrm{e}$ (Ingram, 2012). Neither the red maple LCA nor the current spruce study considered the potential long-term storage of carbon from plant roots left in the soil at the end of life, but the impact could be significant (IPCC, 2006; McPherson and Simpson, 1999; Mokany et al., 2006) and should be addressed in further research.

Sensitivity analysis of input variable GWP revealed that a $10 \%$ increase in a given variable would result in at least a $1 \%$ increase in the total GWP investment for eight of the 86 variables in the model in the production and distribution phases. A $10 \%$ increase in carbon sequestered in production would decrease the seed-to-landscape C footprint by $7 \%$, whereas a $10 \%$ decrease in the GWP investment from digging, loading on a wagon, hauling from the field, loading the truck, and $\mathrm{N}$ applied in field production would yield a $3 \%, 2 \%, 3 \%, 1 \%$, and $1 \%$ decrease in the seed-to-landscape carbon footprint, respectively. A $10 \%$ decrease in traveling distance to the landscaper and to the landscape site would each decrease the carbon footprint by $2 \%$. Analysis of the aggregated components of the model showed that $\mathrm{C}$ sequestered in the use phase and GHG emissions invested in the end-of-life takedown and disposal and during production had the greatest impact on the life cycle carbon footprint in that order. A 10\% change in C sequestration during its useful life phase would result in a $14 \%$ change in life cycle carbon footprint. Carbon sequestration during the use phase is definitely the major variable in the overall model and, therefore, the greatest potential for introduction of errors. Although the literature revealed that the GWP of agricultural lime is highly variable, a $10 \%$ increase would only result in a $0.02 \%$ increase to the carbon footprint. This illustrates the need for nursery managers and researchers to focus on possible modifications of system inputs and activities that could have the greatest impact on GWP.

The capacity to query the model system through LCA allows "what if" modification of system components to determine the overall impact of those modifications. In the current model, it was determined from nursery manager interviews throughout the region that the length of time required to produce a 2 -m-tall colorado blue spruce from a $2+2$ liner varied from four to six years. The model presented here was based on a five-year production cycle plus a fallow year with a cover crop. Querying the model revealed that adding an additional year to production in the field nursery would only add $0.412 \mathrm{~kg} \mathrm{CO}_{2} \mathrm{e}$, less than $3 \%$, to the seed-to-landscape GWP of the product. Drought conditions could result in more irrigation requirements. If four 
additional irrigations were applied during field production, it would increase the seed-to-landscape carbon footprint by $0.50 \mathrm{~kg} \mathrm{CO} 2 \mathrm{e}(3.6 \%)$. Increasing the cull rate from $20 \%$ to $30 \%$ in the second liner production phase would only add $0.004 \mathrm{~kg} \mathrm{CO}_{2} \mathrm{e}$ to the final product, but increasing the cull rate from $10 \%$ to $20 \%$ in the field nursery phase would add $1.085 \mathrm{~kg} \mathrm{CO}_{2} \mathrm{e}$. This is primarily the result of the high-density production in the liner phase compared with the field production phase. Reducing the number of mowing passes by five $(25 \%)$ during field production would decrease the GWP by $0.0439 \mathrm{~kg} \mathrm{CO} 2 \mathrm{e}$, but reducing the equipment use in harvesting by only $10 \%$ would decrease the GWP by $1.22 \mathrm{~kg} \mathrm{CO}_{2} \mathrm{e}$. Reducing the transport distance of the final product by $25 \%$ would decrease the seed-to-landscape carbon footprint by $0.608 \mathrm{~kg} \mathrm{CO}_{2} \mathrm{e}(5 \%)$.

LCA has proven to be an effective tool to analyze the environmental impact of production system components and to estimate the life cycle impact of trees on the environment. Nursery managers and the consuming public can use information generated through this and other studies to make production system and purchasing decisions. Additional work is needed to determine the environmental impact of other classes of landscape plants and to link the impacts of inputs to economic and market consequences.

\section{Literature Cited}

Aldentun, Y. 2002. Life cycle inventory of forest seedling productionFrom seed to regeneration site. J. Clean. Prod. 10:47-55.

Baumann, H. and A.-M. Tillman. 2004. The hitch hiker's guide to LCA: An orientation in life cycle assessment methodology and application. Studentlitteratur, Lund, Sweden.

Brentrup, F. and C. Palliere. 2008. GHG emissions and energy efficiency in European nitrogen fertiliser production and use. Intl. Fert. Soc. Proc. 639:2-28.

BSI British Standards. 2011. Specification for the assessment of the life cycle greenhouse gas emissions of goods and services. PAS 2050:2011. BSI British Standards, London, UK.

Burnham, A., M. Wang, and Y. Wu. 2006. Development and applications of GREET 2.7-The transportation vehicle-cycle model. ANL/ ESD/06-5. 25 Sept. 2012. <http://greet.es.anl.gov/pdfs/TA/378.PDF>. Cambria, D. and D. Pierangeli. 2011. A life cycle assessment case study for walnut tree (Juglans regia L.) seedlings production. Intl. J. Life Cycle Assessment 16:859-868.

Debolt, S., J.E. Campbell, R. Smith, M. Montross, and J. Stork. 2009. Life cycle assessment of native plants and marginal lands for bioenergy agriculture in Kentucky as a model for south-eastern USA. Global Change Biol. Bioenergy 1:308-316.

Fleming, L.E. 1988. Growth estimates of street trees in central New Jersey. MS thesis, Rutgers University, New Brunswick, NJ.

Grisso, R., J. Perumpral, D. Vaughan, G. Roberson, and R. Pitman. 2010. Predicting tractor diesel fuel consumption. Virginia Coop. Ext. Publ. 442-073.

Hayashi, K., G. Gaillard, and T. Nemecek. 2006. Life cycle assessment of agricultural production systems: Current issues and future perspectives. Proc. Intl. Seminar on Technol. Dev. for Good Agr. Practices in Asia and Oceania. Translated by Food and Fert. Tech. Ctr., Taipei, Taiwan. p. 98-110.

Hillier, J., C. Hawes, G. Squire, A. Hilton, S. Wale, and P. Smith. 2009. The carbon footprints of food crop production. Intl. J. Agr. Sustainability 7:107-118.

Ingram, D. 2012. Life cycle assessment of a field-grown red maple tree to estimate its carbon footprint components. Intl. J. Life Cycle Assessment 17:453-462.

Intergovernmental Panel on Climate Change. 2006. Guidelines for national greenhouse gas inventories. Volume 4: Agriculture, forestry and other land use. Chapter 11: $\mathrm{N}_{2} \mathrm{O}$ emissions from managed soils, and $\mathrm{CO}_{2}$ emissions from lime and urea application. 25 Sept. 2012. $<$ http://www.ipcc-nggip.iges.or.jp/public/2006gl/vol4.html $>$.

Intergovernmental Panel on Climate Change. 2007. IPCC fourth assessment report. Climate change 2007. 25 Sept. 2012. <http://www.ipcc.ch/ publications_and_data/publications_and_data_reports.shtml $>$.

International Organization for Standardization. 2006. Life cycle assessment, requirements and guidelines. ISO Rule 14044:2006. Intl. Organization for Standardization, Geneva, Switzerland.

Kendall, A. and E.G. McPherson. 2012. A life cycle greenhouse gas inventory of a tree production system. Intl. J. Life Cycle Assessment 17:444-452.

Lal, R. 2004. Carbon emissions from farm operations. Environ. Intl. 30:981-990.

Liebig, M.A., M.R. Schmer, K.P. Vogel, and R.B. Mitchell. 2008. Soil carbon storage by switchgrass grown for bioenergy. BioEnergy Res. 1:215-222.

Marble, S.C., S.A. Prior, G.B. Runion, H.A. Torbert, C.H. Gilliam, and G.B. Fain. 2011. The importance of determining carbon sequestration and greenhouse gas mitigation potential in ornamental horticulture. HortScience 46:240-244.

McPherson, E.G. and J.R. Simpson. 1999. Carbon dioxide reduction through urban forestry guidelines for professional and volunteer tree planters. U.S. Dept. Agr., For. Serv., Pacific Southwest Res. Sta., Gen. Tech. Rpt. PSWGTR-171.

Mokany, K., R.J. Raison, and A.S. Prokushkin. 2006. Critical analysis of root:shoot ratios in terrestrial biomes. Glob. Change Biol. 12:8496.

Mourad, A.L., L. Coltro, P.A.P.L.V. Oliveira, R.M. Kletecke, and J.P.O.A. Baddini. 2007. A simple methodology for elaborating the life cycle inventory of agricultural products. Intl. J. Life Cycle Assessment 12:408-413.

Nemecek, T., D. Dubois, L. Gunst, and G. Gaillard. 2005. Life cycle assessment of conventional and organic farming in the DOC trial. Researching sustainable systems. Proc. First Scientific Conf. Intl. Soc. Organic Agr. Res. (ISOFAR), Intl. Federation Organic Agr. Movements (IFOAM), Natl. Assn. Sustainable Agr. Australia (NASAA), Adelaide, South Australia, 21-23 Sept. 2005. p. 222-226. Nemecek, T., D. Dubois, L. Gunst, and G. Gaillard. 2006. Life cycle assessment of Swiss organic farming systems. Asp. Appl. Biol. 79: $15-18$.

Nowak, D.J. 1994. Atmospheric carbon dioxide reduction by Chicago's urban forest, p. 83-94. In: McPherson, E.G., D.J. Nowak, and R.A. Rowntree (eds.). Chicago's urban forest ecosystem: Results of the Chicago Urban Forest Climate Project. U.S. Dept. Agr., For. Serv., Northeastern For. Expt. Sta., Gen. Tech. Rpt. NE-186.

Nowak, D.J., J.C. Stevens, S.M. Sisinni, and C.J. Luley. 2002. Effects of urban tree management and species selection on atmospheric carbon dioxide. J. Arboricult. 28:113-122.

Prior, S.A., G.B. Runion, S.C. Marble, H.H. Rogers, C.H. Gilliam, and H.A. Torbert. 2011. A review of elevated atmospheric $\mathrm{CO}_{2}$ effects on plant growth and water relations: Implications for horticulture. HortScience 46:158-162.

Russo, G., P. Buttol, and M. Tarantini. 2008. LCA (life cycle assessment) of roses and cyclamens in greenhouse cultivation. Acta Hort. 801:359366.

Russo, G. and G.S. Mugnozza. 2005. LCA methodology applied to various typology of greenhouses. Acta Hort. 691:837-843.

Russo, G. and B.D.L. Zeller. 2008. Environmental evaluation by means of LCA regarding the ornamental nursery production in rose and sowbread greenhouse cultivation. Acta Hort. 801:1597-1604.

Samaras, C. and K. Meisterling. 2008. Life cycle assessment of greenhouse gas emissions from plug-in hybrid vehicles: Implications for policy. Environ. Sci. Technol. 42:3170-3176.

Snyder, C.S., T.W. Bruulsema, T.L. Jensen, and P.E. Fixen. 2009. Review of greenhouse gas emissions from crop production systems and fertilizer management effect. Agr. Ecosyst. Environ. 133:247266. 
United Nations. 1987. The Montreal protocol on substances that deplete the ozone layer. 25 Sept. 2012. <http://montreal-protocol. org/new_site/en/Treaties/treaties_decisions-hb.php?sec_id=5>.

U.S. Department of Agriculture. 2008. CUFR tree carbon calculator. 25 Sept. 2012. <http://www.fs.fed.us/ccrc/topics/urban-forests/ctcc/>. U.S. Department of Energy. 1998. Method of calculating carbon sequestration by trees in urban and suburban settings. 25 Sept. 2012. <ftp://ftp.eia.doe.gov/pub/oiaf/1605/cdrom/pdf/sequester. pdf>.

U.S. Department of Energy. 2012. U.S. Life-cycle inventory database. 25 Sept. 2012. <https://www.lcacommons.gov/nrel/search>.

U.S. Environental Protection Agency. 2005. Emission facts: Average carbon dioxide emissions resulting from gasoline and diesel fuel. EPA420-F-05_001.26 Sept. 2012. <http://www.epa.gov/otaq/climate/ 420f05001.htm>.

U.S. Environmental Protection Agency. 2010. Ozone layer protectionScience. 26 Sept. 2012. <http://www.epa.gov/ozone/science/ods/ classone.html>.
U.S. Environmental Protection Agency. 2012. Ozone layer protectionRegulatory program; List of critical uses. 26 Sept. 2012. <www.epa.gov/ ozone/mbr/cueuses.html>.

Vyas, A. and M. Singh. 2011. GREET1_2011 (greenhouse gases, related emissions, and energy use in transportation). 25 Sept. 2012. $<$ http://www.transportation.anl.gov/modeling_simulation/VISION/>.

Wang, M. 2007. The greenhouse gases, regulated emissions, and energy use in transportation (GREET) model. 25 Sept. 2012. <http:// www.transportation.anl.gove/software/Greet/index.html>.

West, T.O. and G. Marland. 2002a. Net carbon flux from agricultural ecosystems: Methodology for full carbon cycle analyses. Environ. Pollut. 116:437-442.

West, T.O. and G. Marland. 2002b. A synthesis of carbon sequestration, carbon emissions, and net carbon flux in agriculture: Comparing tillage practices in the United States. Agr. Ecosyst. Environ. 91:217-232.

Williams, A.G., E. Audsley, and D.L. Sandars. 2006. Energy and environmental burdens of organic and non-organic agriculture and horticulture. Asp. Appl. Biol. 79:19-23. 